\section{Genetic progress of the peach breeding program of Embrapa over 16 years}

\section{Elisia Rodrigues Corrêa ${ }^{1}$, Maicon Nardino ${ }^{2 *}$, Willian Silva Barros $^{1}$ and Maria do Carmo Bassols Raseira ${ }^{3}$}

\begin{abstract}
The peach breeding program of the Brazilian Agricultural Research Corporation (Embrapa), addressing the adaptation to mild winter conditions, is one of the largest in the world and maintains a germplasm collection of nearly 900 accessions. The objective was to estimate the genetic progress in fruit weight (FW) and fruit development period (FDP) resulting from the above program, by analyzing data records of 16 years (2000 - 2015) of 65 genotypes. Based on samples of $\geq 10$ fruits, the mean annual FW (in g) and FDP (in number of days) from full flowering to harvest were determined. In the 16 years, the gain in FDP consisted of respective reductions of about -12.8, -3.3,-2.8 days for canning peach, fresh peach and nectarine. However, the genetic progress in fruit weight was 5.3, 1.4 and $-17.9 \mathrm{~g}_{\text {fruit }}{ }^{-1}$ for canning peach, fresh peach and nectarine, respectively.
\end{abstract}

Keywords: Prunus persica; canning peach, fresh peach, fruit development period, fruit weight

\section{INTRODUCTION}

Peach, Prunus persica (L. Batsh), belongs to the family Rosaceae, is the most important temperate fruit species worldwide (Raseira et al. 2018). It originated in China, where the greatest genetic variability is found. Prior to the introduction in America, it was cultivated in Iran and Europe (Sachs et al. 1984).

In 1532, Martin Afonso de Souza brought the peach to Brazil (Embrapa 2003). According to FAOSTAT (2017), a peach and nectarine production of $248,583 \mathrm{t}$ was recorded in 2017. Rio Grande do Sul (RS) is the largest peach-producing state in Brazil, responsible for more than half of the total Brazilian production (IBGE 2006). It is worth mentioning that Pelotas, where the Embrapa breeding program is located, and the surrounding counties are responsible for nearly $30 \%$ of the total Brazilian peach production and account for $95.3 \%$ of the area producing canning peach.

A peach breeding program was initiated at the Agronomic Institute of Campinas (IAC) in 1947 and a second one in 1963 at the plant science station of Taquari, by the secretariat of agriculture of Rio Grande do Sul. Around 1955, the breeding program of Taquari was transferred to Pelotas (currently at Embrapa Temperate Climate) (Raseira and Nakasu 2002). To date, both programs are still active, working on the development of low-chill cultivars.
Crop Breeding and Applied Biotechnology 19(3), 319-328, 2019 Brazilian Society of Plant Breeding. Printed in Brazil http://dx.doi.org/10.1590/198470332019v19n3a44 


\section{ER Corrêa et al.}

The peach breeding program of Embrapa Temperate Climate, where a germplasm collection with nearly 900 accessions is maintained, is one of the largest in the world. The collection contains genetic variability mainly for traits such as low-chill requirement, resistance to Monilinia fructicola, pest tolerance and high fruit quality, among others (Frazon and Raseira 2014).

Few studies have described the genetic progress in peach in Brazil. Therefore, this study is essential, for estimating the genetic progress of the Peach Breeding Program of Embrapa Temperate Climate, by analyzing fruit weight and development period (cycle) data of 65 genotypes over a 16 -year period.

\section{MATERIAL AND METHODS}

\section{Plant Material}

A total of 65 peach genotypes (28 varieties and 37 selections) were selected for the study. Data of fruit weight (FW, in g) and fruit development period (FDP - number of days from flowering to harvest), recorded from 2000 to 2015, were used. The peach type, parents and ancestors of the accessions are listed in Tables 1 and 2.

\section{Experimental design}

The experimental design was completely randomized with three plants per genotype. Trees were planted 2 - 3m apart, in rows spaced $5-6 \mathrm{~m}$ apart. Pest control was applied as recommended for the region (Medeiros and Raseira 1998). Nitrogen fertilization was applied at the beginning of sprouting and after harvest. At the time of fruit thinning, $\mathrm{K}$ and $\mathrm{P}$ were applied when necessary.

Assessing the genetic gain by the methodology of Vencovsky et al. (1988) has the objective of analyzing the genetic progress of traits under real field conditions. This methodology allows the use of data from trials of a historic series. The proposed model estimates genetic gains, where the genetic progress balance is established by the method of generalized least squares (Cruz et al. 2014).

The Vencovsky et al. (1988)'s method calculates the genetic gain for each biennium based on the linear regression model: $\hat{G}_{g}=\left(\overline{\mathrm{Y}}_{2}-\overline{\mathrm{Y}}_{1}\right)-\left(\overline{\mathrm{y}}_{2}-\overline{\mathrm{y}} \mathrm{c}_{1}\right)$ (equation 1), where: $\hat{\mathrm{G}}_{g}=$ Estimation of genetic gain, $\overline{\mathrm{Y}}_{1}=$ overall cultivar mean in the year 1 trial, $\bar{y}_{2}=$ overall cultivar mean in the year 2 trial, $\bar{y} c_{1}=$ mean of common cultivars in the year 1 trial, and $\bar{y} c_{2}=$ mean of common cultivars in the year 2 trial. By this methodology, the gross difference is computed by $\left(\bar{y}_{2}-\bar{y}_{1}\right)$ and the environmental difference by $\left(\bar{y} c_{2}-\bar{y} c_{1}\right)$. In this way, the genetic gain is estimated by the gross difference minus the environmental difference (Vencovsky et al. 1988). The genetic progress balance is determined by the generalized least squares, as described by Cruz et al (2014), resulting in the mean genetic gain of the period $\left(\mu \hat{G}_{g}\right)$. The annual genetic progress percentage (PG) is calculated by the expression $\left(\frac{\mu \hat{G}_{g}}{\bar{y}_{i}} \times 100\right)$ (Equation 2).

The following tools can be used for the evaluation of the dynamics of cultivars in a breeding program, underlying evaluations of investments for a new cultivar release: Cultivar replacement rates (substitution of varieties by newly released, improved peach varieties); percentage of inclusion (\% percentage of newly released varieties); percentage of exclusion (\%E percentage of excluded varieties); percentage of maintenance (\%M percentage of marketed varieties remaining on the market); and percentage of renewal (\%R ratio given by the percentage of included and maintained varieties).

The assessment of these rates can be estimated as follows:

$$
\% I=\frac{100 I}{M+E+I} \text { (equation 3), \%E }=\frac{100 E}{M+E+I} \text { (equation 4), \%M = } \frac{100 M}{M+E+I} \text { (equation 5), \%R= } \frac{100 I}{M+I} \text { (equation 4), }
$$

where: $I$ = number of cultivars included in the subsequent year; $E=$ number of cultivars excluded in the previous year; $M=$ number of cultivars maintained from one year to the next; and $R=$ renewal of cultivars (Cruz et al. 2014). The data file of the peach breeding program of Embrapa Temperate Climate at Pelotas was recorded in Excel and later analyzed with software Genes (Cruz 2016). 


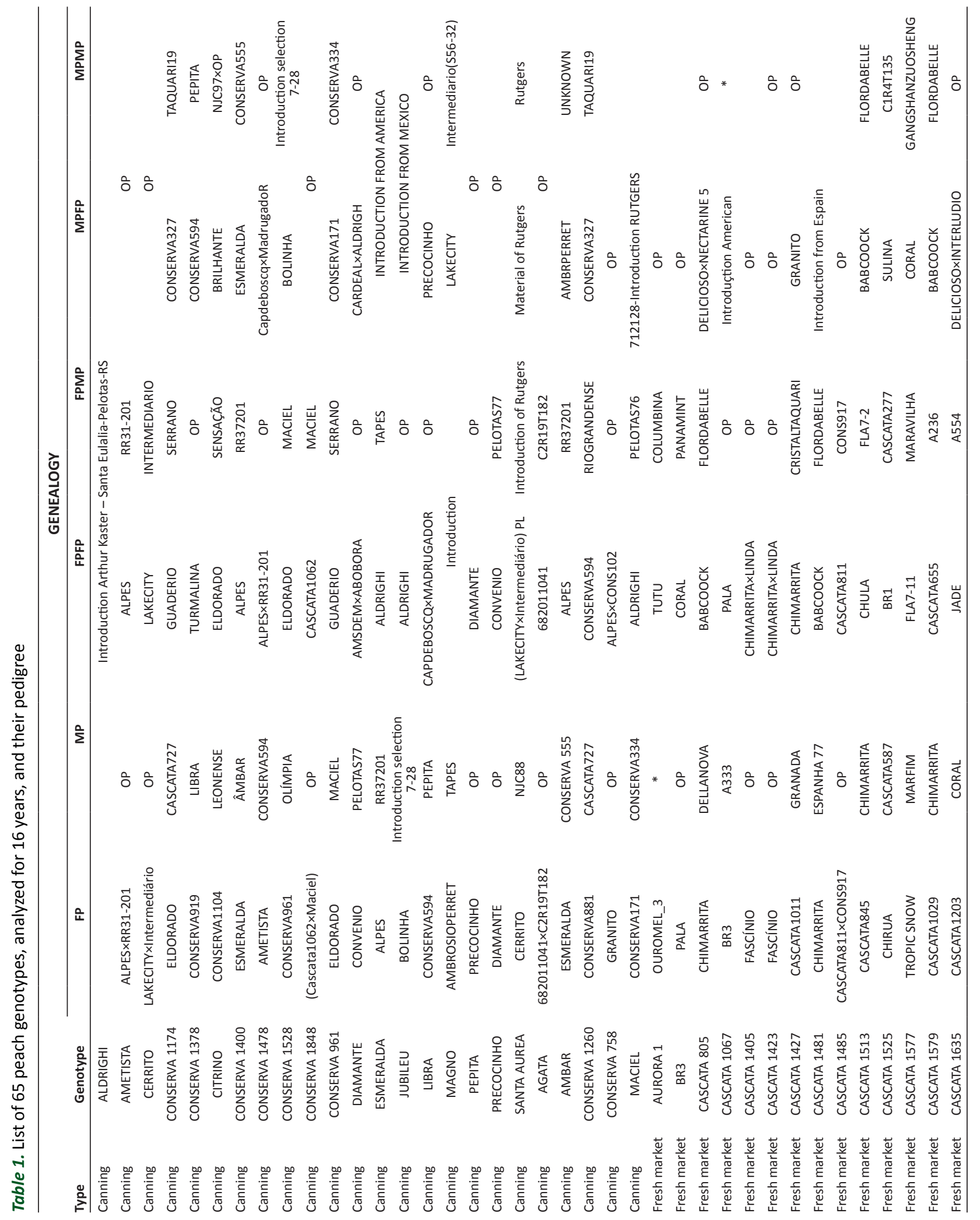




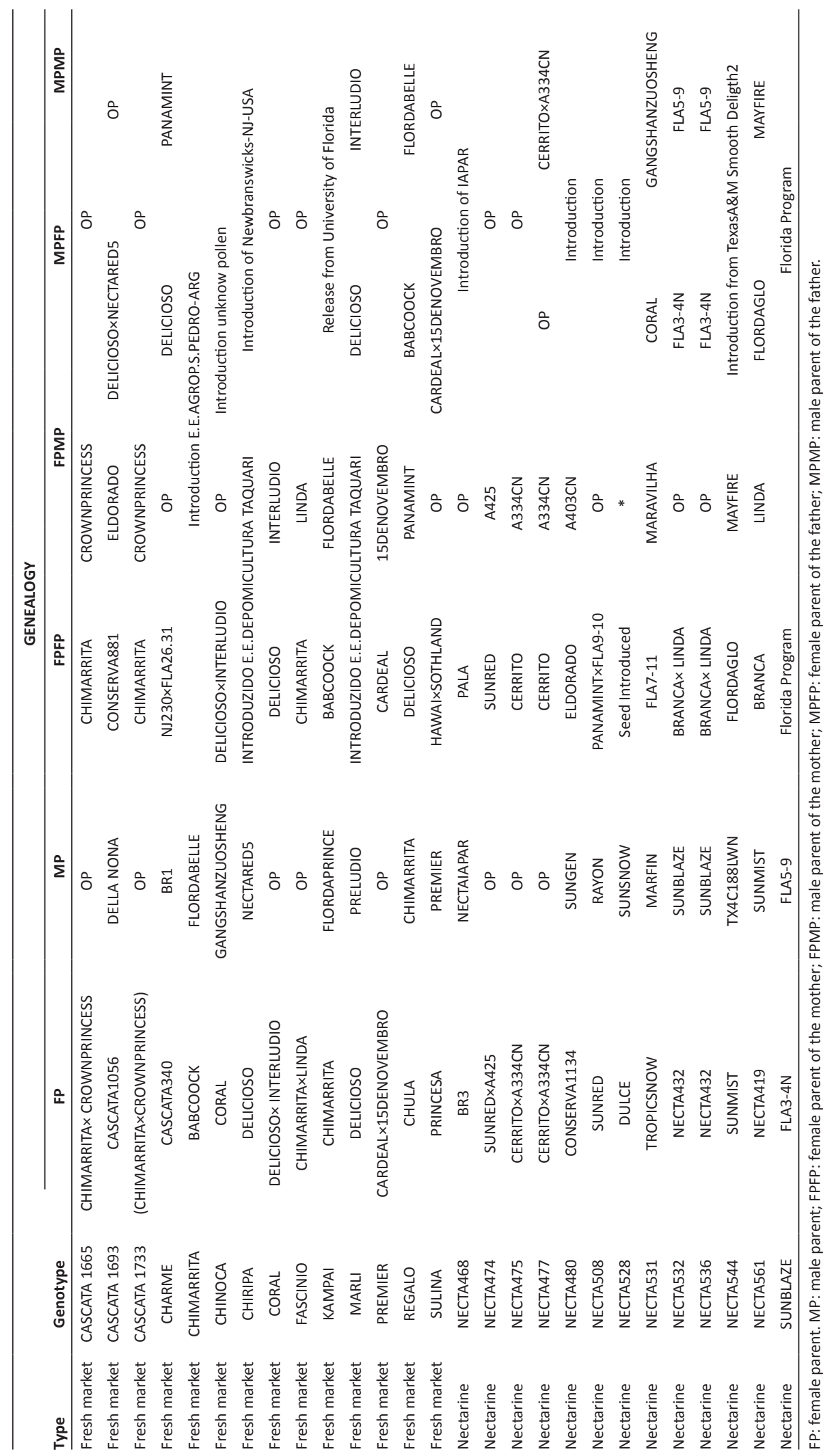




\section{RESULTS AND DISCUSSION}

The data of 16 years of peach trials of the Embrapa peach breeding program had a balanced distribution between genotypes and years (Figure 1). Of the 19 evaluated canning peach genotypes, eight had a renewal rate of $>50 \%$. In 2005 , the inclusion rate of new genotypes for this peach type was high (6 genotypes), of which four were evaluated throughout the 16 years. Of the 28 evaluated fresh peach genotypes, seven were evaluated during the whole study period. In 2007, a high rate of new peach progenies was assessed in the breeding program. A total of 13 nectarine genotypes were evaluated, of which a large number was introduced in 2005 in the breeding program (Table 2).

According to the fruit development period (FDP) data of all 65 genotypes, canning peach genotypes had an inclusion rate of $27.11 \%$, exclusion rate of $27.36 \%$, and renewal rate of $33.01 \%$, all lower than the maintenance rate, $45.51 \%$ (Table 2). The maintenance rate was lower than that reported in genetic progress studies for oat (78.8\%) (Follmann et al. 2017), wheat (52\%) (Cargnin et al. 2008) and rice (58\%) (DoVale et al. 2012).

Table 2. Estimates of inclusion, exclusion, maintenance and renewal rates for canning and fresh peach and nectarine based on of 65 peach genotypes during 16 years by the peach breeding program of Embrapa Temperate Climate

\begin{tabular}{|c|c|c|c|c|c|c|c|c|c|c|c|c|}
\hline \multirow[b]{3}{*}{ Biennium } & \multicolumn{12}{|c|}{ Fruit development period } \\
\hline & \multicolumn{3}{|c|}{ Inclusion } & \multicolumn{3}{|c|}{ Exclusion } & \multicolumn{3}{|c|}{ Maintenance } & \multicolumn{3}{|c|}{ Renewal } \\
\hline & ${ }^{\mathrm{a} C} \mathrm{C} \_\mathrm{D}$ & ${ }^{\mathrm{b}} \mathrm{M}$ & ${ }^{\mathrm{c}} \mathrm{N}$ & C_D & $\mathrm{M}$ & $\mathrm{N}$ & C_D & $\mathrm{M}$ & $\mathrm{N}$ & C_D & $\mathrm{M}$ & $\mathrm{N}$ \\
\hline $01 / 00$ & $0.0 \%$ & $0.0 \%$ & $0.0 \%$ & $50.0 \%$ & $36.4 \%$ & $0.0 \%$ & $50.0 \%$ & $63.6 \%$ & $100.0 \%$ & $0.0 \%$ & $0.0 \%$ & $0.0 \%$ \\
\hline $02 / 01$ & $30.0 \%$ & $0.0 \%$ & $0.0 \%$ & $10.0 \%$ & $14.3 \%$ & $100.0 \%$ & $60.0 \%$ & $85.7 \%$ & $0.0 \%$ & $33.3 \%$ & $0.0 \%$ & $0.0 \%$ \\
\hline 03/02 & $18.2 \%$ & $40.0 \%$ & $100.0 \%$ & $9.1 \%$ & $20.0 \%$ & $0.0 \%$ & $72.7 \%$ & $40.0 \%$ & $0.0 \%$ & $20.0 \%$ & $50.0 \%$ & $100.0 \%$ \\
\hline 04/03 & $9.1 \%$ & $11.1 \%$ & $0.0 \%$ & $9.1 \%$ & $22.2 \%$ & $100.0 \%$ & $81.8 \%$ & $66.7 \%$ & $0.0 \%$ & $10.0 \%$ & $14.3 \%$ & $100.0 \%$ \\
\hline 07/06 & $87.5 \%$ & $100.0 \%$ & $100.0 \%$ & $0.0 \%$ & $0.0 \%$ & $0.0 \%$ & $12.5 \%$ & $0.0 \%$ & $0.0 \%$ & $87.5 \%$ & $100.0 \%$ & $100.0 \%$ \\
\hline 08/07 & $50.0 \%$ & $45.5 \%$ & $40.0 \%$ & $12.5 \%$ & $18.2 \%$ & $0.0 \%$ & $37.5 \%$ & $36.4 \%$ & $60.0 \%$ & $57.1 \%$ & $55.6 \%$ & $40.0 \%$ \\
\hline 09/08 & $17.6 \%$ & $43.8 \%$ & $16.7 \%$ & $23.5 \%$ & $0.0 \%$ & $16.7 \%$ & $58.5 \%$ & $56.3 \%$ & $66.7 \%$ & $23.1 \%$ & $43.8 \%$ & $20.0 \%$ \\
\hline $10 / 09$ & $31.6 \%$ & $20.0 \%$ & $50.0 \%$ & $10.5 \%$ & $30.0 \%$ & $0.0 \%$ & $57.9 \%$ & $50.0 \%$ & $50.0 \%$ & $35.3 \%$ & $28.6 \%$ & $50.0 \%$ \\
\hline $11 / 10$ & $15.0 \%$ & $22.2 \%$ & $9.1 \%$ & $15.0 \%$ & $11.1 \%$ & $18.2 \%$ & $70.0 \%$ & $66.7 \%$ & $72.7 \%$ & $17.6 \%$ & $25.0 \%$ & $11.1 \%$ \\
\hline \multirow[t]{3}{*}{$15 / 14$} & $42.1 \%$ & $44.4 \%$ & $0.0 \%$ & $21.1 \%$ & $11.1 \%$ & $100.0 \%$ & $36.8 \%$ & $44.4 \%$ & $0.0 \%$ & $53.3 \%$ & $50.0 \%$ & $83.3 \%$ \\
\hline & \multicolumn{12}{|c|}{ Fruit weight } \\
\hline & \multicolumn{3}{|c|}{ Inclusion } & \multicolumn{3}{|c|}{ Exclusion } & \multicolumn{3}{|c|}{ Maintenance } & \multicolumn{3}{|c|}{ Renewal } \\
\hline Biennium & C_D & $M$ & $\mathrm{~N}$ & C_D & $M$ & $\mathrm{~N}$ & C_D & $\mathrm{M}$ & $\mathrm{N}$ & C_D & $M$ & $\mathrm{~N}$ \\
\hline $01 / 00$ & $0.0 \%$ & $0.0 \%$ & $0.0 \%$ & $50.0 \%$ & $45.5 \%$ & $0.0 \%$ & $50.0 \%$ & $54.5 \%$ & $100.0 \%$ & $0.0 \%$ & $0.0 \%$ & $0.0 \%$ \\
\hline $02 / 01$ & $30.0 \%$ & $14.3 \%$ & $0.0 \%$ & $10.0 \%$ & $14.3 \%$ & $100.0 \%$ & $60.0 \%$ & $71.4 \%$ & $0.0 \%$ & $33.3 \%$ & $16.7 \%$ & $0.0 \%$ \\
\hline $03 / 02$ & $18.2 \%$ & $40.0 \%$ & $100.0 \%$ & $9.1 \%$ & $20.0 \%$ & $0.0 \%$ & $72.7 \%$ & $40.0 \%$ & $0.0 \%$ & $20.0 \%$ & $50.0 \%$ & $100.0 \%$ \\
\hline 04/03 & $9.1 \%$ & $11.1 \%$ & $0.0 \%$ & $9.1 \%$ & $22.2 \%$ & $100.0 \%$ & $81.8 \%$ & $66.7 \%$ & $0.0 \%$ & $10.0 \%$ & $14.3 \%$ & $100.0 \%$ \\
\hline 05/04 & $16.7 \%$ & $30.0 \%$ & $100.0 \%$ & $33.3 \%$ & $30.0 \%$ & $0.0 \%$ & $50.0 \%$ & $40.0 \%$ & $0.0 \%$ & $25.0 \%$ & $42.9 \%$ & $100.0 \%$ \\
\hline 06/05 & $50.0 \%$ & $30.0 \%$ & $0.0 \%$ & $25.0 \%$ & $30.0 \%$ & $0.0 \%$ & $25.0 \%$ & $40.0 \%$ & $100.0 \%$ & $66.7 \%$ & $42.9 \%$ & $0.0 \%$ \\
\hline $14 / 13$ & $6.3 \%$ & $15.8 \%$ & $25.0 \%$ & $31.3 \%$ & $42.1 \%$ & $50.0 \%$ & $62.5 \%$ & $42.1 \%$ & $25.0 \%$ & $90.9 \%$ & $27.3 \%$ & $50.0 \%$ \\
\hline $15 / 14$ & $35.3 \%$ & $42.1 \%$ & $60.0 \%$ & $11.8 \%$ & $5.3 \%$ & $20.0 \%$ & $52.9 \%$ & $52.6 \%$ & $20.0 \%$ & $40.0 \%$ & $44.4 \%$ & $75.0 \%$ \\
\hline
\end{tabular}

${ }^{\mathrm{a}}$ Canning peach; ${ }^{\mathrm{b}}$ Fresh peach; ${ }^{\mathrm{c}}$ Nectarine. 


\section{ER Corrêa et al.}

For the same variable FDP, the fresh peach genotypes had inclusion rates of $27.84 \%$, exclusion rates of $25.87 \%$ and renewal rates of $38.2 \%$ in the studied period. Once again, the maintenance rate was the highest (Table 2). The analysis of mean rates of FDP of nectarine, considering all 65 genotypes, resulted in an inclusion rate of $31.72 \% \%$, exclusion rate of $41.66 \%$ and renewal rate of $59.4 \%$ in the studied period. These percentages were higher than that of the maintenance rate $(26.63 \%)$ (Table 2$)$.

With regard to the FW of all 65 peach genotypes, the mean rates were estimated as $21.47 \%$ for inclusion, $21.59 \%$ for exclusion and $32.25 \%$ for renewal. For the period from 2000 to 2015, these rates were lower than the maintenance rate $(56.96 \%)$ (Table 2$)$.

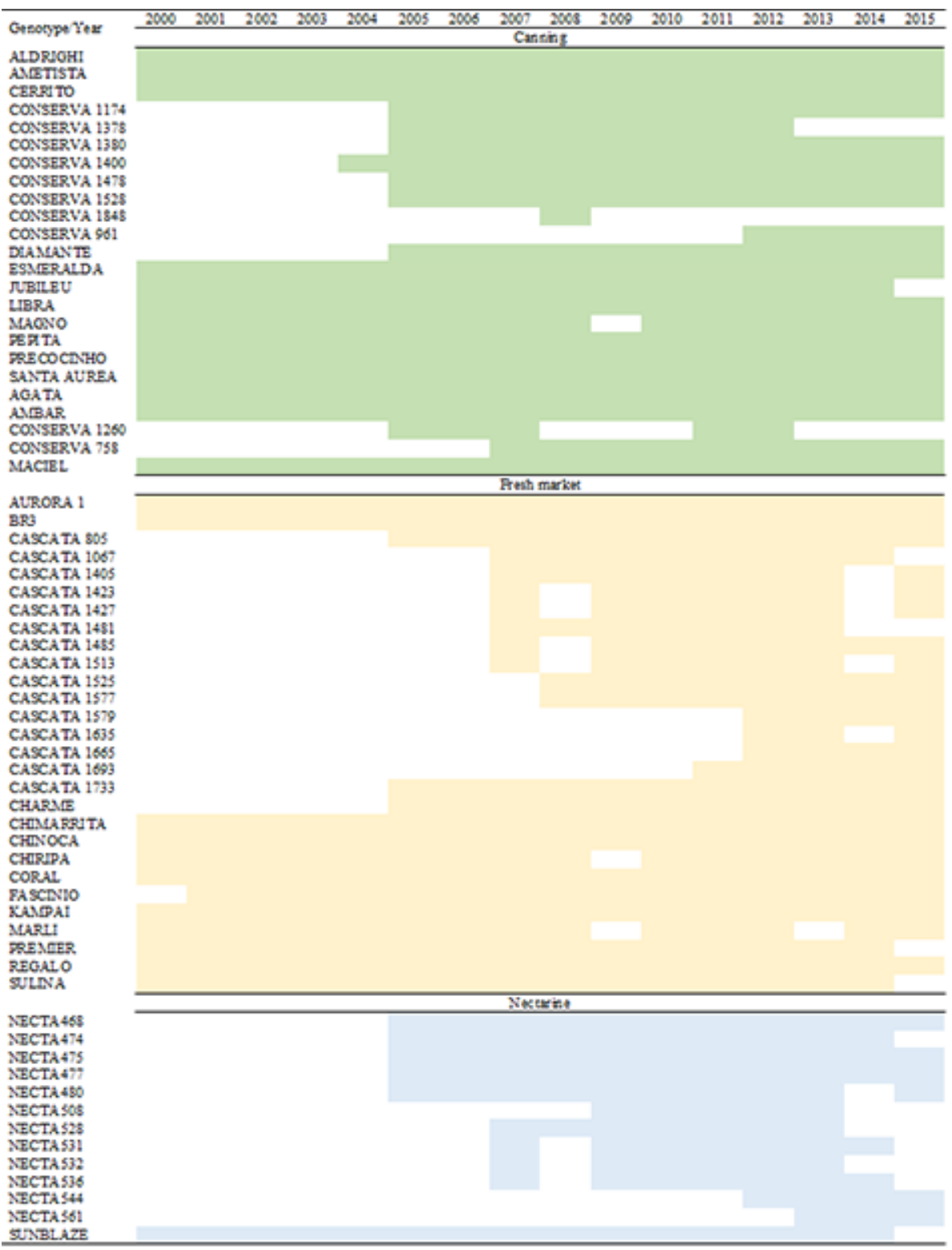

Figure 1. Chronological relation of the evaluation of different types of peach and nectarine, in 16 years in the peach breeding program of Embrapa Temperate Climate. 
Likewise, the mean rates for nectarine FW were estimated at $32.96 \%$ inclusion rate, $28.93 \%$ exclusion and renewal of $44.92 \%$, for the study period, exceeding the maintenance rate (38.11\%) (Table 2 ).

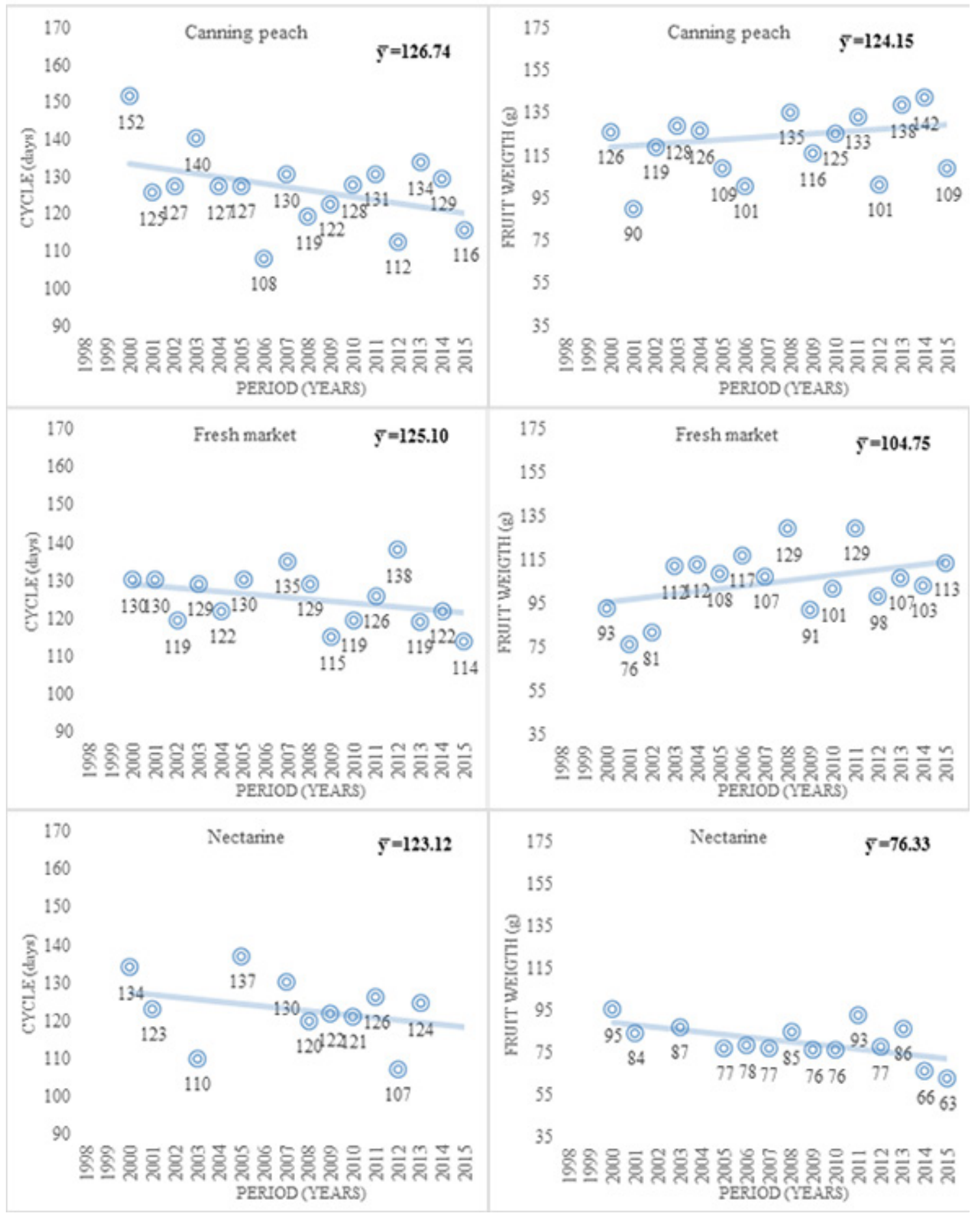

Figure 2. Annual mean of fruit development period and fruit weight of 65 peach genotypes evaluated for 16 years by the peach breeding program of Embrapa Temperate Climate. 


\section{ER Corrêa et al.}

The mean data of the two variables (fruit development period and fruit weight) indicated a linear decrease in FDP, regardless of the fruit type and an increase in mean FW for canning and fresh peach (Figure 2).

The overall mean FDP was 126.74 days for canning peach, with a decrease to 116 days in the growing season of 2015. In other words, there was a reduction of 10 days over the studied period. For fresh peach, the overall mean was 125 days and the mean in the last growing season 114 days (2014/2015), i.e., a reduction of 9 days. For nectarine, the overall mean was the lowest of the three fruit types, with 123 days. A shorter FDP is one of the goals of the Embrapa breeding program for all selected peach types (Figure 1).

The overall mean of all years for FW was estimated by analyzing each fruit type throughout the study period (Figure 2). A mean of $124.14 \mathrm{~g}$ fruit $^{-1}$ was obtained for canning peach. A slight linear increase was observed for this peach type. A similar trend can be observed for fresh peach, with a mean of $104 \mathrm{~g}_{\text {fruit }}{ }^{-1}$, that is, almost $20 \mathrm{~g} \mathrm{fruit}^{-1}$ less than canning peach. However, FW over 16 years showed a relevant increase, from a mean of $93 \mathrm{~g}_{\text {fruit }}^{-1}$ to $113 \mathrm{~g}$ fruit $^{-1}$, corresponding to a gain of $21 \%$ in relation to the first season. On the other hand, for nectarine there was a significant decrease, of > $30 \mathrm{~g}$, compared to the first growing season (2000), which means that the mean FW was $33 \%$ less at the end than at the beginning of the evaluated period. Many factors may have caused this loss. Since nectarine is very susceptible to Monilinia fructicola, in this region, the fruits are usually picked before they are fully ripe, i.e., before they can grow to full size. The number of genotypes sampled were roughly half of those of each peach type. But most importantly, the genetic basis of the Embrapa nectarine collection is narrower than that of any peach type. The reference year of evaluation was 2000, thus the means of each fruit type were estimated based on the mean of the genotypes in that year.

In line with one of the breeding objectives of Embrapa, the estimates of mean genetic gain $(\mu \mathrm{G})$ for FDP were negative, with reductions of $-18.7,-4.3$ and -3.8 days (Table 2 ) in canning peach, fresh peach and nectarine, respectively. Canning peach had far higher genetic gain estimates than the other types developed by the breeding program. This reflects the continuous search for early genotypes for inclusion in the breeding program, with a view to the release for cultivation in the region. The mean genetic gain for FW for canning and fresh peach was positive (5.83 and 1.26 $\mathrm{g}$ fruit ${ }^{-1}$, respectively) (Table 3). However, for nectarine, the mean genetic gain was negative and high (-17.03 $\left.\mathrm{g} \mathrm{fruit}^{-1}\right)$. These results show the importance of variability in the breeding program. The number of nectarine accessions in the breeding program was always lower when compared to table and canning peach types. Moreover, as already mentioned, nectarine is more susceptible to pests and fungi, especially as the orchard gets older.

An analysis of the genetic progress in the peach program for FDP (Table 3) showed a trend towards a reduction of the cycle, a consequence of which is an earlier harvest. Both the industrial sector and farmers prefer an earlier harvest to reduce production costs and improve the fruit price on the market. This was more significant for canning peach, which showed a 4-fold genetic progress compared to fresh peach and almost 5-fold compared to nectarine. It should also be emphasized that in spite of the higher reduction in FDP, canning peach also had the highest genetic gain in mean FW. This fact confirms that this peach type was prioritized by Embrapa in Pelotas, since it is the most commonly cultivated in the region. In contrast, there was a negative genetic progress (-17.93) for nectarine FW, indicating the need to introduce new high-yielding genotypes with large fruits.

The peach breeding program at Embrapa Temperate Climate has been active since 1963, developing and testing genotypes adapted to the South of Rio Grande do Sul (RS), Brazil and lately to the Southeastern region of Brazil. Until today, its contributions are highly valuable, since most cultivars cultivated in Brazil resulted from the Embrapa breeding program. Peach production can be an alternative income source for local growers and provide industries and the local as well as national market with raw fruit (Feliciano 1979).

In the beginning of the peach breeding program, the top priority was the development of cultivars for canning, which is maintained until today. Cultivar Algrighi was the only one producing fruits for the canneries of RS. Its fruits are harvested in the second half of December for around 15 days, resulting in difficulties of harvesting and industrialization due to the short time in which it have to be processed. The first early-maturing cultivars were derived from open pollinations of 'Aldrighi' or from material introduced from overseas. However, the resulting cultivars were not much earlier than cv. Aldrighi. In 1970, there was a huge improvement with the release of cultivar Diamante, which produced harvestable fruits 20 to 30 days earlier than 'Aldrighi'. 
Genetic progress of the peach breeding program of Embrapa over 16 years

Table 3. Genetic gain balance of the peach breeding program of Embrapa Temperate Climate during the years 2000 to 2015 , for fruit development period (FDP - days) and fruit weight (FW - g) considering 65 genotypes, distributed in peach types (canning peach, fresh peach and nectarine)

\begin{tabular}{lcccccc}
\hline Type/Trait & \multicolumn{3}{c}{ Mean 2000* } & & $\boldsymbol{\mu ~ G}$ & \multicolumn{1}{c}{ GP (\%) } \\
\hline & FDP & FW & FDP & FW & FDP & FW \\
\cline { 2 - 7 } Canning peach & 151.50 & 125.85 & -18.77 & 5.83 & -12.76 & 5.34 \\
Fresh peach & 130.00 & 92.63 & -4.28 & 1.26 & -3.29 & 1.36 \\
Nectarine & 134.00 & 95.00 & -3.78 & -17.03 & -2.82 & -17.93 \\
\hline
\end{tabular}

* Genotype means, GP: genetic progress.

One of the goals of the Embrapa Temperate Climate peach breeding program are genotypes with early maturing fruits and preferably with a short FDP. Hybridizations were made over the years with earlier maturing fresh market cultivars, as the best hybrids were obtained by backcrosses with canning cultivars or selections. During the 16 years of study, FDP was significantly reduced, in spite of variations among the years, which may be related to climate variations, mainly in terms of temperature. In 2009, cultivar BRS Libra, the first protected clingstone cultivar in Brazil, was released. In the same year, cv. BRS Kampai was released as the first protected fresh peach cultivar in the country. Depending on the climate conditions, the beginning of harvesting for BRS Libra varies from the last week of September to the first of October, i.e., a nearly 50 days earlier harvest than the mean time at the beginning of the program (Raseira 2010). Apart from this cultivar, others such as cv. BRS Citrino, Ágata, Pepita and Santa Áurea were also developed for an earlier peach production.

Great efforts were made to increase mean FW, which was successful, in particular for the canning genotypes. However, this was not the case with nectarine, which was derived from less diversified germplasm and was not a priority compared to peach, and to date the nectarine-producing area in Brazil is still insignificant. As the international nectarine market is increasing, Embrapa should invest more in this segment in the coming years, introducing new accessions and making more hybridizations with this botanical variety $P$. persica nucipersica.

\section{CONCLUSIONS}

The Embrapa Peach Breeding Program has been successful in shortening the FDP, with an estimated genetic progress of $-12.7,-3.2$ and 2.8 days for canning peach, fresh peach and nectarine, respectively, in the 16-year evaluation.

Regarding the goal of developing genotypes with higher FW, the progress in canning peach was more successful than in fresh peach $(5.3,1.36$, respectively). On the other hand, a reduction in nectarine FW (genetic progress of -17.9 $\mathrm{g}_{\text {fruit }}{ }^{-1}$ over 16 years) was observed, indicating the need to pay particular attention to this trait.

\section{REFERENCES}

Cargnin A, Souza MA and Fronza V (2008) Progress in breeding of irrigated wheat for the cerrado region of Brazil. Crop Breeding Applied Biotechnology 8: 39-46.

Cruz CD, Carneiro PCS and Regazzi AJ (2014) Modelos biométricos aplicados ao melhoramento genético. $3^{\text {th }}$ edn, vol 2, UFV, Viçosa, $668 \mathrm{p}$.

Cruz CD (2016) Genes Software - Extended and Integrated with the R, Matlab and Selegen. Acta Scientiarum Agronomy 38: 547-552.

DoVale JC, Soares PC, Cornélio VMO, Reis MS, Borges V, Bisi RB, Soares AA and Fritsche-Neto R (2012) Contribuição genética na produtividade do arroz irrigado em Minas Gerais no período de 1998 a 2010. Bragantia 71: 460-466

Embrapa (2003) Sistema de produção de pêssego de mesa na região da Serra Gaúcha. Bento Gonçalves. Available at: <http://
sistemasdeproducao.cnptia.embrapa.br/FontesHTML/Pessego/ PessegodeMesaRegi aoSerraGaucha/conducao.htm>. Accessed on March 20, 2017.

FAOSTAT - Food of Agriculture Organization of the United Nations (2017) Productions indices. Available at: <http://www.fao.org/faostat/ en/\#data/QI>. Accessed on Jan 10, 2018.

Feliciano AJ (1979) Melhoramento genético do pessegueiro no Brasil. In $5^{\text {th }}$ Congresso brasileiro de fruticultura. UEPAE, Pelotas, p. 881-885.

Follmann DN, Cargnelutti Filho A, Lúcio AD, Souza VQ, Caraffa M and Wartha CA (2017) Genetic progress in homogeneous regions of wheat cultivation in Rio Grande do Sul state, Brazil. Genetics and Molecular Research 16: 1-9.

Franzon R and Raseira MCB (2014) Melhoramento genético. In Raseira MCB, Pereira JFM and Carvalho FLC (eds) Pessegueiro. Embrapa, Brasília, p. 57-72. 


\section{ER Corrêa et al.}

IBGE - Instituto Brasileiro de Geografia e Estatística (2006) Censo agropecuário. Available at:

<http://www.ibge.gov.br/home/estatistica/economia/agropecuaria/ censoagro/2006_segunda_apuracao/default.shtm>. Accessed on March 21, 2017.

Medeiros CAB and Raseira MCB (1998) A cultura do pessegueiro. Embrapa-SPI, Brasília, 350p.

Raseira MCB and Nakasu BH (2002) Pessegueiro. In Bruckner CH (ed) Melhoramento de fruteiras de clima temperado. UFV, Viçosa, 186p.

Raseira MCB (2010) Pêssego cultivar BRS Libra. Revista Brasileira de Fruticultura 32: 961-1296.
Raseira MCB, Franzon RC, Pereira JFM, Scaranari C and Feldberg NP (2018) Peach cultivar BRS Citrino. Crop Breeding and Applied Biotecnology 18: 234-236

Sachs S, Herter FG, Nakasu BH, Raseira MCB, Feliciano AJ, Camellato $D$, Medeiros ARM, Raseira A, Fonseca VO, Pereira JFM, Finardi NL, Magnani M, Fehn LM, Salles LAB, Feliciano A, Cantillano RFF and Sperry S (1984) A cultura do pessegueiro. Pelotas, Embrapa-CNPFT, Pelotas, 156p. (Circular Técnica, 10).

Vencovsky R, Morais AR, Garcia JC and Teixeira NM (1988) Progresso genético em vinte anos de melhoramento do milho no Brasil. In $16^{\text {th }}$ Congresso nacional de milho e sorgo. Embrapa- CNPMS, Sete Lagoas, p. 300-307. 